\title{
LH prevents cisplatin-induced apoptosis in oocytes and preserves female fertility in mouse
}

\author{
Valerio Rossi ${ }^{1}$, Monica Lispi ${ }^{2}$, Salvatore Longobardi ${ }^{3}$, Maurizio Mattei ${ }^{4}$, Francesca Di Rella ${ }^{5}$, Antonietta Salustri ${ }^{1}$, Massimo De Felici, \\ and Francesca G Klinger ${ }^{*, 1}$
}

Premature ovarian failure and female infertility are frequent side effects of anticancer therapies, owing to the extreme sensitivity of the ovarian reserve oocytes to the damaging effects of irradiation and chemotherapy on DNA. We report here a robust protective effect of luteinizing hormone (LH) on the primordial follicle pool of prepubertal ovaries against the cisplatin (Cs)-induced apoptosis. In vitro LH treatment of prepubertal ovarian fragments generated anti-apoptotic signals by a subset of ovarian somatic cells expressing LH receptor (LHR) through cAMP/PKA and Akt pathways. Such signals, reducing the oocyte level of pro-apoptotic TAp63 protein and favoring the repair of the Cs-damaged DNA in the oocytes, prevented their apoptosis. Noteworthy, in vivo administration to prepubertal female mice of a single dose of LH together with Cs inhibited the depletion of the primordial follicle reserve caused by the drug and preserved their fertility in reproductive age, preventing significant alteration in the number of pregnancy and of delivered pups. In conclusion, these findings establish a novel ovoprotective role for LH and further support the very attracting prospective to use physiological 'fertoprotective' approaches for preventing premature infertility and risks linked to precocious menopause in young patients who survived cancer after chemotherapy.

Cell Death and Differentiation (2017) 24, 72-82; doi:10.1038/cdd.2016.97; published online 30 September 2016

In mammals, the growing follicles develop from a pool of primordial follicles constituted early in life. Despite a current lively debate, ${ }^{1}$ such follicles, termed the ovarian reserve, represent probably the only pool available for ovulation in the mammalian females during their entire reproductive life.

Premature ovarian failure and infertility are routine side effects of anticancer therapies, owing to the extreme sensitivity of the ovarian reserve oocytes, mainly to the DNA-damaging effects of irradiation (IR) and chemotherapic drugs. ${ }^{2,3}$

At present, methods to preserve future fertility in cancer patients are invasive and in some cases still at experimental level. ${ }^{4}$ The development of chemotherapic agents that do not harm the ovarian reserve, or of substances capable of protecting oocytes from the deleterious effects of such drugs ('fertoprotective agents') would represent a major improvement to preserve fertility in women. ${ }^{5}$

Several laboratories have recently investigated the molecular pathways involved in the death of oocytes exposed to IR or chemotherapic drugs. According to the current model, the alpha TAp63 isoform, found in the nucleus of oocytes, is a key mediator of the DNA damage response in the primordial follicle oocytes. ${ }^{6-10}$ Studies from our and other laboratories have indicated that the co-treatment with $c-A B L$ inhibitors has a significant protective effect on the ovarian reserve challenged by cisplatin (Cs), a chemotherapic drug used to treat different types of cancer, likely preventing TAp63 activation.,11 Accordingly, other reports showed that TAp63 activation increases the expression of PUMA and NOXA, causing oocyte apoptosis ${ }^{12}$ and that pharmacological inhibition of c-ABL impinges on an integrated p53 family-signaling network (involving both TAp63 and TAp73), reducing BAX/ BAK-mediated oocyte apoptosis. ${ }^{13}$

Other compounds, such as sphingosine-1-phosphate (S1P) or the S1P mimetic FTY720, ${ }^{14-16}$ dexrazoxane, ${ }^{17}$ AS101, ${ }^{18}$ sildelnafil citrate, ${ }^{19}$ tamoxifen, ${ }^{20}$ have also been shown to act as primordial follicle protective agents after IR and/or chemotherapy.

Administration of gonadotropin-releasing hormone agonists $(\mathrm{GnRHa})$ during chemotherapy has been reported to be beneficial for fertility preservation in adolescent mammalian females, ${ }^{21-23}$ opening the exiting possibility of using biological molecules with targeted action. However, the effectiveness and mechanisms of action of $\mathrm{GnRHa}$, in protecting the ovarian reserve from chemotherapy-induced damage, is still debated. ${ }^{24-26}$

In the present work, we hypothesized that luteinizing hormone (LH) and follicle-stimulating hormone (FSH) may exert a protective action on the oocytes of the ovarian reserve against apoptosis induced by $\mathrm{Cs}$. The physiological functions of these gonadotropins are well delineated in the adult. ${ }^{27-30}$ Much less characterized is the function that $\mathrm{LH}$ and $\mathrm{FSH}$ may exert on the early stages of folliculogenesis. Earlier studies in humans have demonstrated that FSH receptors are expressed in follicles from primary to later stages $^{31}$ and

${ }^{1}$ Department of Biomedicine and Prevention, University of Rome Tor Vergata, Rome, Italy; ${ }^{2}$ Medical Affair Department Fertility TA, Merck-Serono SAS, Rome, Italy; ${ }^{3}$ Global Medical Affair, Merck KGaA, Darmstadt, Germany; ${ }^{4} \mathrm{STA}$, Department of Biology, University of Rome 'Tor Vergata', Rome, Italy and ${ }^{5} \mathrm{UOC}$ Oncologia Medica Senologica, Istituto Nazionale per lo Studio e la Cura dei Tumori, Fondazione G. Pascale, Naples, Italy

${ }^{*}$ Corresponding author: M De Felici or FG Klinger, Department of Biomedicine and Prevention, University of Rome Tor Vergata, Via Montpellier 1, Rome 00133, Italy. Tel: +393 355217 424; Fax: +390 672596 174; E-mail: klinger@uniroma2.it or defelici@uniroma2.it

Abbreviations: LH, luteinizing hormone; Cs, cisplatin; LHR, luteinizing hormone receptor; IR, irradiation; FSH, follicle-stimulating hormone; GnRHa, gonadotropinreleasing hormone agonists; POs, primordial oocytes; GOs, growing oocytes; FRSK, forskolin; Cx, carbenoxolone; KL, Kit ligand

Received 13.6.16; revised 18.7.16; accepted 20.7.16; Edited by RA Knight; published online 30.9.16 
treatment with $\mathrm{FSH}$ and $\mathrm{LH}$ promotes preantral follicle growth. ${ }^{32,33}$ In differentiating rodent gonads, a truncated $\mathrm{LH}$ receptor (LHR) mRNA can be detected even before gonad formation, whereas the first full-length LHR has been detected in rat and mouse ovaries at 5 days post partum. ${ }^{34,35}$

In vitro and in vivo results reported here show that $\mathrm{LH}$, and at lesser extent $\mathrm{FSH}$, has the ability to protect the primordial follicle pool present in the ovaries of prepuberal mice against Cs-induced apoptosis of, thereby preserving their future fertility in the reproductive age.

\section{Results}

LH protects POs from degeneration induced by $\mathrm{Cs}$ in culture. Ovaries from GFP-cKit transgenic mice of 4 days post partum (P4) were cut into small fragments and cultured for 4 days in order to allow spreading of ovarian somatic cells and facilitate the score of the fluorescent oocytes under the microscope; cultures were then exposed for $24 \mathrm{~h}$ to two different doses of Cs. We found that the number of the primordial follicle-enclosed oocytes (diameter $<20 \mu \mathrm{m}$, hereafter termed as primordial oocytes, POs) was severely reduced in the ovarian fragments, incubated in the presence of $\mathrm{Cs}$ in comparison with untreated cells (Figures 1a and b) (\% morphologically healthy POs, mean \pm S.E.: $\mathrm{Ctrl}=96 \pm 1.2 ; 7.5 \mu \mathrm{M}$ Cs $=54 \pm 3.8 ; 10 \mu \mathrm{M} \mathrm{Cs}=33 \pm 1.1)$. Differently, we observed that the few primary/secondary follicleenclosed oocytes (hereafter termed as growing oocytes, GOs) were unaffected by the Cs treatment (Figure 1a). In order to determine whether these results were due to a stagedependent oocyte sensitivity to $\mathrm{Cs}$, we repeated the same experiments on POs and GOs, isolated from P7 to P8 ovaries and freed from follicle cells. The results showed that while only a few denuded POs survived after $24 \mathrm{~h}$ in the presence of $10 \mu \mathrm{M}$ Cs $(35 / 155=22.6 \%)$, the large majority of GOs (56$160=93 \%$ ) remained healthy as estimated both morphologically and by the Trypan blue test (Supplementary Figure $1 \mathrm{~A}$ and data not shown). Thus, Cs was able to directly induce death in primordial but not GOs in vitro.

Strikingly, we found that pretreatment with $\mathrm{LH}$, in the range of $50-200 \mathrm{mlU} / \mathrm{ml}$ (about $0.6-2.3 \mathrm{ng} / \mathrm{ml}$ ) $1 \mathrm{~h}$ before $\mathrm{Cs}$ addition, favored in a dose-dependent manner the survival of POs within the ovarian fragments after $24 \mathrm{~h}$ of culture, approaching their number to that of the drug-untreated samples (\% healthy POs: $7.5 \mu \mathrm{M} \mathrm{Cs} \pm 200 \mathrm{mlU} \mathrm{LH}=80 \pm 3.6$; $10 \mu \mathrm{M} \mathrm{Cs}+200 \mathrm{mlU} \mathrm{LH}=68 \pm 3.0$ ) (Figures $1 \mathrm{a}$ and $\mathrm{b}$ and Supplementary Figure 1B). Noteworthy, LH did not prevent degeneration of POs cultured either freed from pregranulosa cells (data not shown) or enclosed in the follicles isolated from ovarian fragments (Supplementary Figure 1C).

Interestingly, we found that $\mathrm{LH}$ was also able to sustain the survival of the ovarian somatic cells that was clearly impaired by Cs treatment, as evaluated by morphological observation and the Trypan blue assay (Supplementary Figure 1D). Overall, these results suggest that LH ovoprotection was actually indirect and mediated by a subset of ovarian somatic cells.

Finally, we found that also FSH had a slight albeit statistically significant protective effect on the Cs ovotoxicity within the ovarian fragments (Figure 1c), but not on POs within isolated follicles, as described with LH (Supplementary Figure 1C).

As LH appeared to exert a significantly much higher ovoprotection than $\mathrm{FSH}$, we focused the subsequent experiments on the LH action.

A subset of the somatic cells of early postnatal ovaries express LHR. Western blotting analyses proved that the LHR was expressed at appraisable level both in postnatal ovaries as early as P2 and in the P4 ovarian fragments cultured for 4 days (Figure 2a). RT-PCR analysis confirmed full-length LHR transcripts in the ovarian somatic cells but not in denuded oocytes obtained from P4 ovaries (Figure 2b). In adult and P8 ovaries, LHR was immunolocalized in cells surrounding the growing follicles (presumably theca cells) (Figure 2c). In P4 ovarian fragments cultured for 4 days, a significant number of LHR-positive cells appeared to surround the region containing the primordial and growing follicles (Figure 2c).

LH ovoprotection against $\mathrm{Cs}$ is mimicked by cAMP increasing agents and requires PKA and AKT activities. cAMP is the canonical second messenger of $\mathrm{LH}^{36}$ In line with this notion, we found that $\mathrm{LH}$ was able to significantly increase the level of cAMP in the ovarian tissue fragments used in our in vitro culture assay (Supplementary Figure 2). Moreover, we found that the addition of 8Br-cAMP (a cell permeable analog of cAMP) to the cultured fragments partly replaced the $\mathrm{LH}$ action and that forskolin (FRSK), a potent activator of adenylate cyclase, completely substituted the LH ovoprotective effect (Figure 3a).

Interestingly, FRSK exerted robust ovoprotection against Cs also on isolated follicle-enclosed and denuded POs (\% healthy follicle-enclosed POs: $10 \mu \mathrm{M} \mathrm{Cs}=15 \pm 2.6$ and $10 \mu \mathrm{M}$ Cs $+10 \mu \mathrm{M}$ FRSK $=58 \pm 3.5$; \% healthy denuded POs: $10 \mu \mathrm{M}$ $\mathrm{Cs}=17 \pm 5$ and $10 \mu \mathrm{M} \mathrm{Cs}+10 \mu \mathrm{M}$ FRSK $=51.4 \pm 9$ ), thus suggesting that high levels of cAMP in the oocyte exerts a protective action against Cs toxicity. In line with this, H89, a specific inhibitor of cAMP-dependent protein kinase (PKA), significantly reduced the LH effect (Figure 3a).

Recent data emphasized that $\mathrm{LH}$, beside PKA activation, may stimulate other signaling pathways, including AKT and ERK kinase activities. ${ }^{37}$ In this respect, we found that two specific inhibitors of PI3K-dependent AKT phosphorylation/ activation, LY294002 and wortmannin, abolished the protective effect of $\mathrm{LH}$ on the POs within the drug-treated ovarian fragments (Figure $3 \mathrm{~b}$ ). The finding that incubation of P7-8 ovaries with LH resulted in increased AKT phosphorylation, further supported the concept that LH ovoprotection involves AKT activation (Figure $3 \mathrm{c}$ ).

Conversely, ERK1/2 kinase activation did not appear to be involved in the LH action in our cell system. In fact, we found that treatment with $C s$ alone increased ERK1/2 phosphorylation/activation in the P7-8 ovaries and that $\mathrm{LH}$ did not significantly affect such increase nor the basal ERK $1 / 2$ activity (Figures 3d and e). Moreover, U0126 (a specific inhibitor of the MEK1-dependent ERK activation) reduced Cs ovotoxicity in the ovarian fragments, preventing the increased ERK1/2 activity associated to Cs action (see also Figure $3 d$ ), 

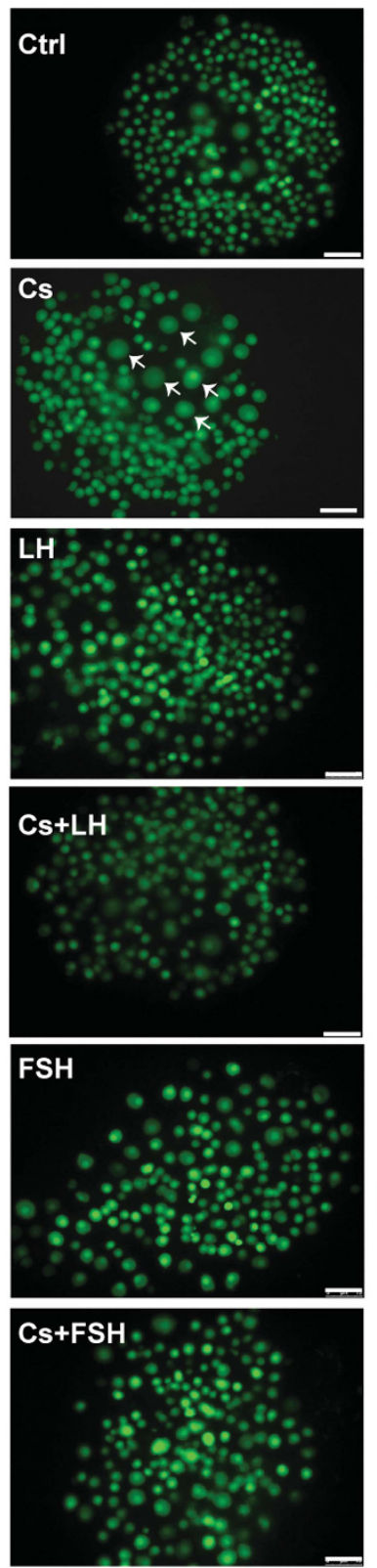

$24 \mathrm{~h}$
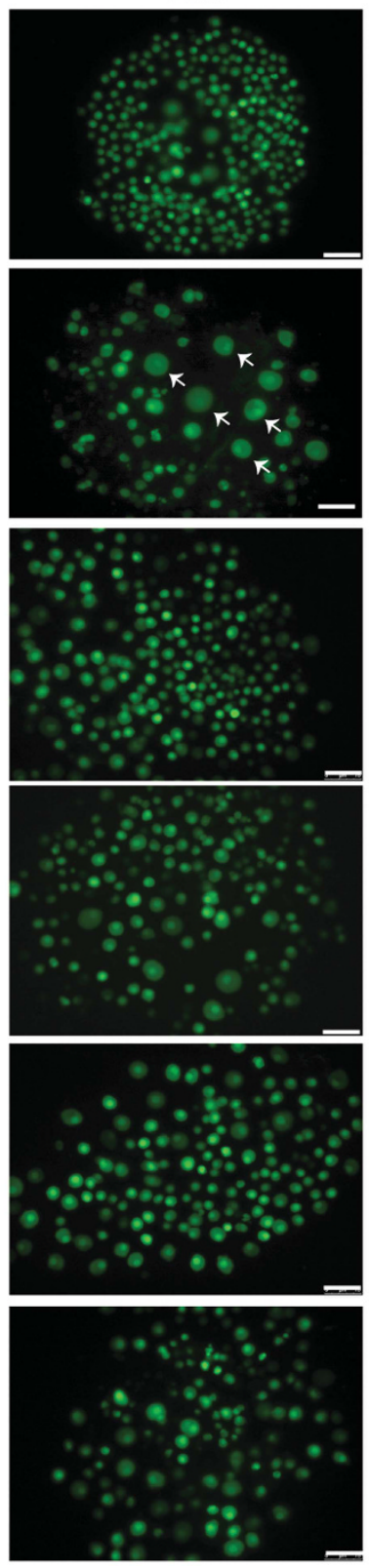

b
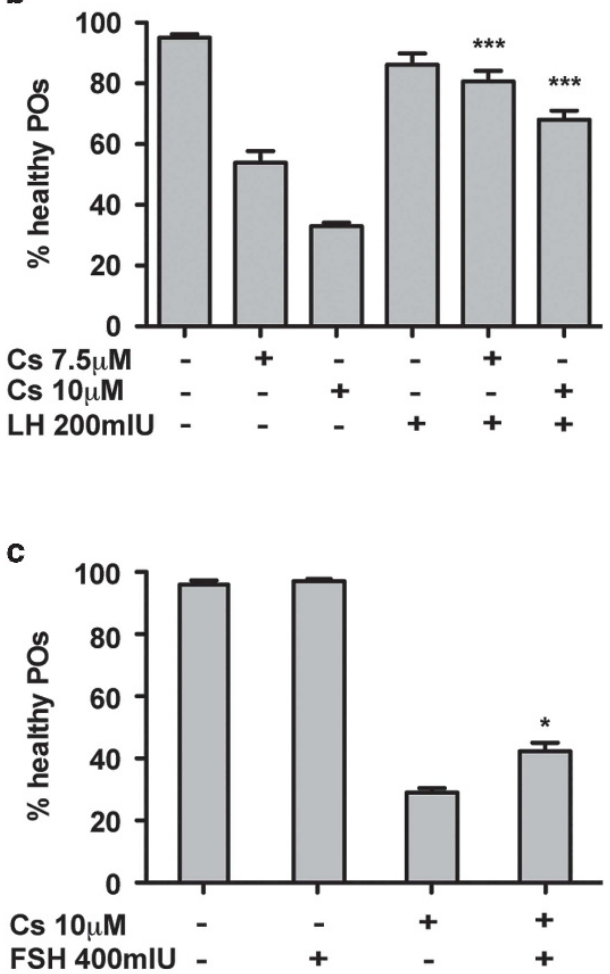

Figure 1 LH protects POs from degeneration induced by Cs. (a) Morphology of ovarian fragments from P4 ovaries of p-18 c-Kit/GFP mice cultured for 4 days (TO) and further $24 \mathrm{~h}$ of culture in the presence of the indicated compounds. GFP-positive POs (diameter $<20 \mu \mathrm{m}$ ) constituted the large majority of the oocyte population in the cultured tissues and, unless otherwise indicated, the only type of oocytes scored in our assay; arrows indicate the few GFP-positive GOs (>20 $\mu \mathrm{m}$ ). Scale bar $75 \mu \mathrm{m}$. (b) Percentage of healthy POs scored after $24 \mathrm{~h}$ culture with/out Cs and LH, mean \pm S.E.: Ctrl $=96 \pm 1.2 ; 7.5 \mu \mathrm{M} \mathrm{Cs}=54 \pm 3.8 ; 10 \mu \mathrm{M} \mathrm{Cs}=33 \pm 1.1 ; 7.5 \mu \mathrm{M} \mathrm{Cs} \pm 200 \mathrm{mlU} \mathrm{LH}=80 \pm 3.6 ; 10 \mu \mathrm{M} \mathrm{Cs}$ $+200 \mathrm{mlU} \mathrm{LH}=68 \pm 3.0$. The values represent the mean \pm S.E. of at least three independent experiments in which at least three fragments were scored for each experimental condition at T0 and after $24 \mathrm{~h}$ of culture. The same procedure and evaluation was used for the compounds and treatments described in all other experiments. (c) Percentage of healthy POs scored after $24 \mathrm{~h}$ of culture with/out Cs and FSH: Ctrl $=95 \pm 1.1 ; 10 \mu \mathrm{M} \mathrm{Cs}=29 \pm 1.4 ; 10 \mu \mathrm{M} \mathrm{Cs}+400 \mathrm{mlU}$ FSH $=42 \pm 2.8$. Statistical differences are versus Cs groups. ${ }^{*} P<0.05,{ }^{* \star *} P<0.001$

without, however, influencing the ovoprotective action of $\mathrm{LH}$ (Figure 3f).

LH ovoprotection against Cs requires functional gap junctions and can be partly replaced by $\mathrm{KL}$. As communications through gap junctions among follicular cells and between follicular cells and the oocyte have a crucial role in the functional interactions that regulate oogenesis, ${ }^{38}$ we investigated whether the $\mathrm{LH}$ ovoprotection against Cs required functional gap junctions. To this aim, we added to the cultured ovarian tissues carbenoxolone (Cx), a prototype gap junction blocker, at a concentration of $100 \mu \mathrm{M} .^{39} \mathrm{Cx}$ did not affect the oocyte survival in control conditions nor influenced the Cs ovotoxicity whereas it completely abolished the $\mathrm{LH}$ ovoprotection against the drug (Figure 4a). 
a
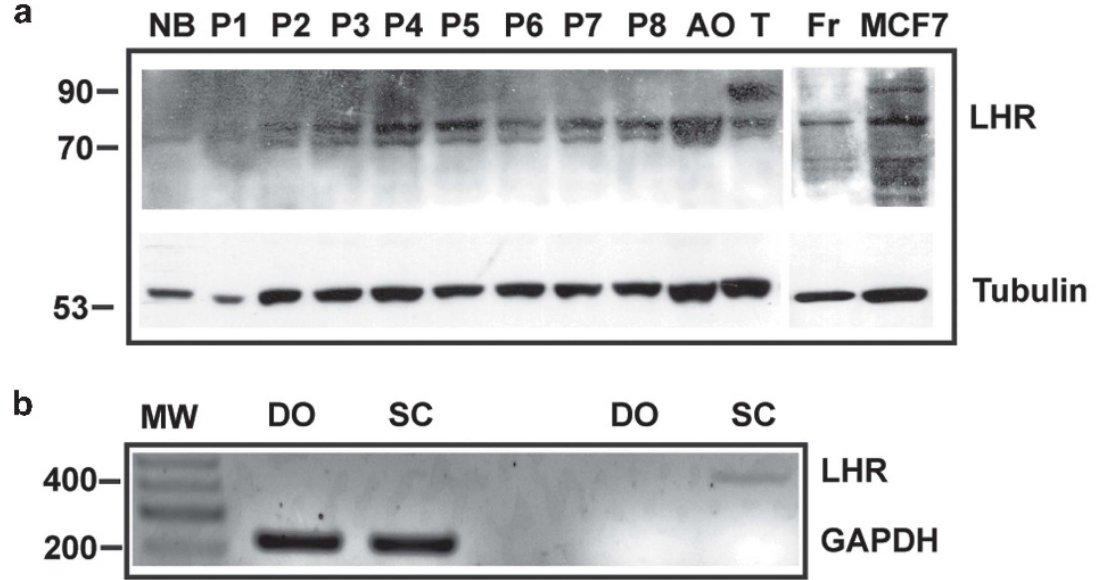

C
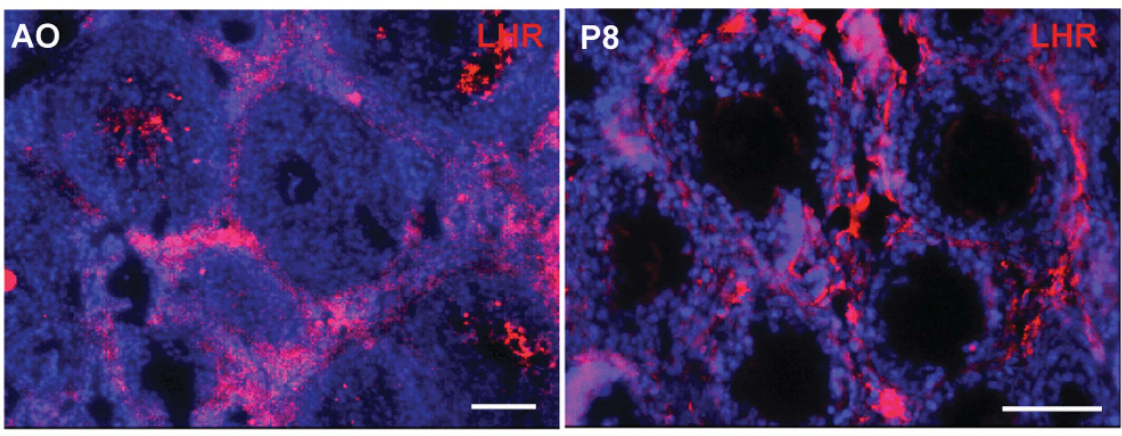

d

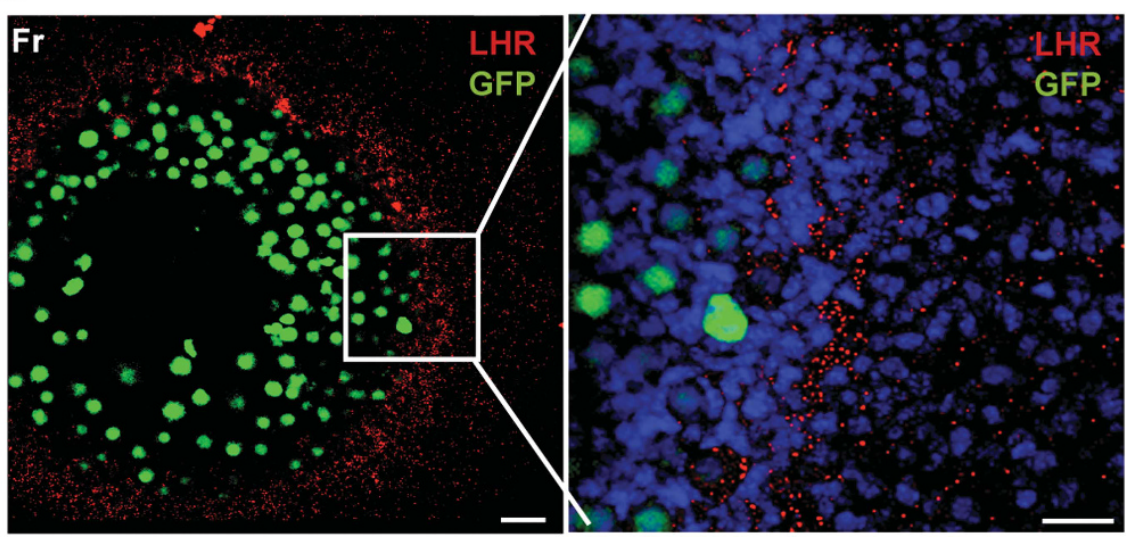

Figure 2 Expression of LHR in ovaries and cultured ovarian tissue fragments. (a) Representative western blotting for LHR performed on samples obtained from ovaries at different developmental stages (NB = new born; $P=$ days after birth) and ovarian fragments (Fr) from $\mathrm{P} 4$ ovaries cultured for 4 days in at least two different experiments; samples from adult ovaries (AO), adult testis (T) and MCF-7 cells, are also shown as positive control. (b) Representative RT-PCR for LHR transcripts performed on samples of denuded oocytes (DO) and ovarian somatic cells (SC) obtained from P4 ovaries. The analysis was repeated at least two times using different samples. (c and d) Immunolocalization of LHR in adult, P8 ovaries and P4 ovarian fragments cultured for 4 days, respectively; (d) right panel, a magnified image of the square region is shown. Scale bar $50 \mu \mathrm{m}$

$\mathrm{LH}$ has been shown to increase $\mathrm{KL}$ expression in granulosa and/or theca cells in the adult ovary. ${ }^{40}$ In line with these results, we found that $\mathrm{LH}$ stimulation increased $\mathrm{KL}$ expression in the P4 ovarian tissue fragments cultured for 4 days and in P8 ovaries as well (Figure 4b). Moreover, we found that in our culture assay the addiction of KL exerted significant ovoprotection against Cs (Figure 4c). Finally, the cytokine exerted ovoprotection both on isolated follicle-enclosed and denuded
POs (\% healthy primordial follicle-enclosed POs: $10 \mu \mathrm{M}$ $\mathrm{Cs}=15 \pm 2.6 ; 10 \mu \mathrm{M} \mathrm{Cs}+100 \mathrm{ng} / \mathrm{ml} \mathrm{KL}=47 \pm 0.7 ; \%$ healthy denuded POs: $10 \mu \mathrm{M}$ Cs $=22 \pm 8.0 ; 10 \mu \mathrm{M} \mathrm{Cs}+100 \mathrm{ng} / \mathrm{ml}$ $\mathrm{KL}=46 \pm 3.4$ ).

The possibility that LH exerted its ovoprotection on the POs through specific factors produced by ovarian somatic cells was next investigated by culturing isolated primordial follicles onto monolayers obtained from ovaries of $\mathrm{P} 7-8$ or of the MCF-7 

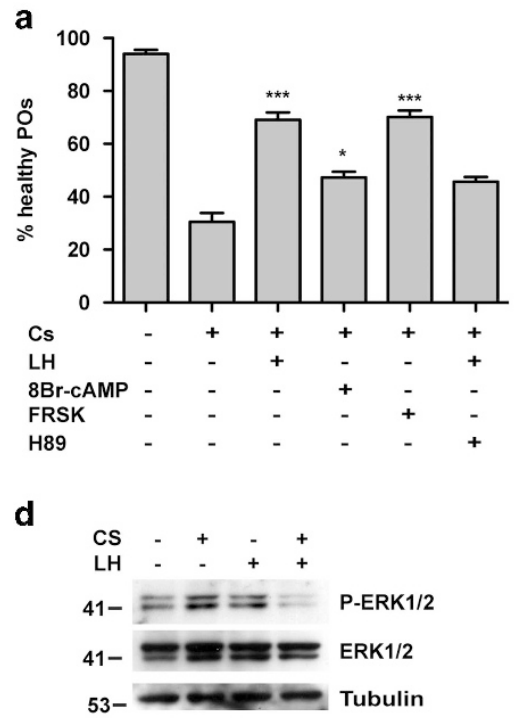

b
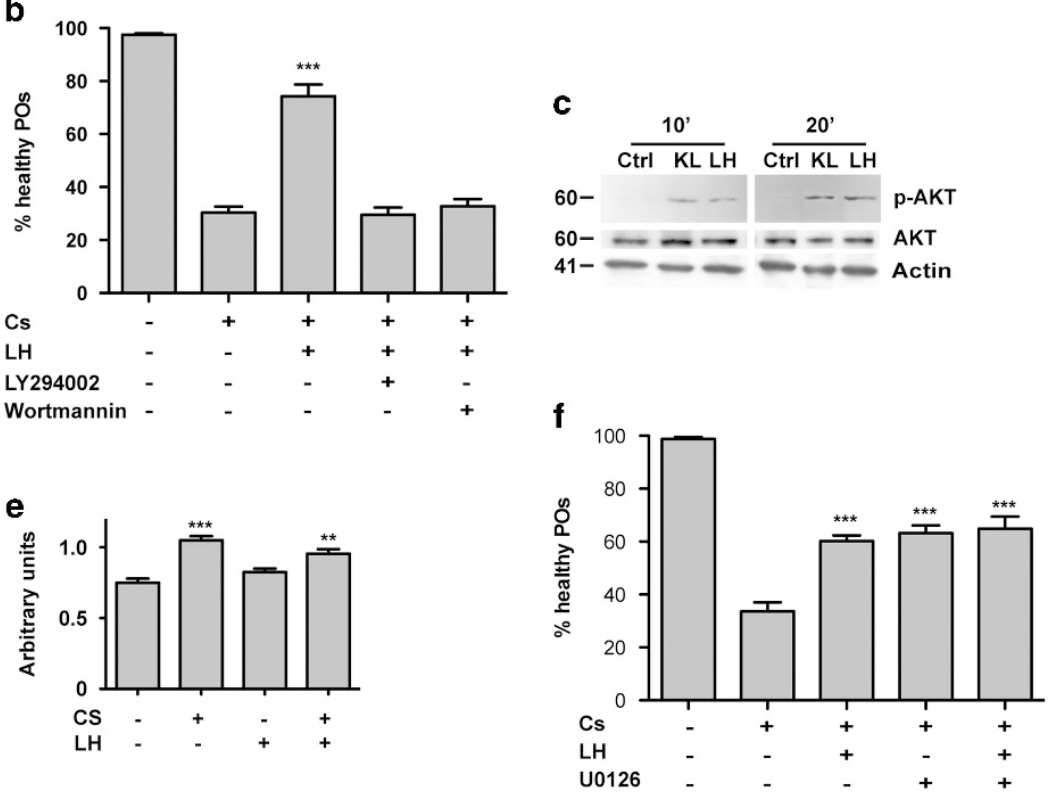

Figure 3 LH ovoprotection against Cs is mimicked by CAMP increasing agents and requires PKA and AKTactivities. (a) Percentage of healthy POs scored within the ovarian fragments after $24 \mathrm{~h}$ of culture: $10 \mu \mathrm{M} \mathrm{Cs}=30 \pm 3.3 ; 10 \mu \mathrm{M} \mathrm{Cs}+200 \mathrm{mlU} \mathrm{LH}=69 \pm 2.7 ; 10 \mu \mathrm{M} \mathrm{Cs}+1 \mathrm{mM} 8 \mathrm{Br}-\mathrm{cAMP}=47 \pm 2.1 ; 10 \mu \mathrm{M} \mathrm{Cs}+10 \mu \mathrm{M} \mathrm{FRSK}=70 \pm 2.5 ; 10 \mu \mathrm{M}$ Cs $+200 \mathrm{mlU}$ LH $+100 \mu \mathrm{M} \mathrm{H} 89=46 \pm 1.8$ or (b) $10 \mu \mathrm{M} \mathrm{Cs}=30 \pm 2.3 ; 10 \mu \mathrm{M} \mathrm{Cs}+200 \mathrm{mlU}$ LH=74 $\pm 4.4 ; 10 \mu \mathrm{M} \mathrm{Cs}+200 \mathrm{mlU}$ LH $10 \mu \mathrm{M}$ LY294002=30 $\pm 2.7 ; 10 \mu \mathrm{M}$ Cs $+200 \mathrm{mlU} \mathrm{LH}+0.1 \mu \mathrm{M}$ wortmannin $=33 \pm 2.7$. Statistical differences are versus $\mathrm{Cs}$ groups. (c) A representative western blotting (out of at least two performed in different samples) for AKT, p-AKT of P8 ovaries treated for 10, 20,30 min with $200 \mathrm{mlU} \mathrm{LH}$; incubation of the ovaries in $100 \mathrm{ng} / \mathrm{ml} \mathrm{KL}$ is shown as a positive control. (d) A representative western blotting (out of at least two performed in different samples) for pERK1/2 and ERK1/2 of ovaries of the same age treated for $20 \mathrm{~min}$ with/out Cs and LH. (e) Densitometric analysis of pERK1/2 western blots. Statistical differences are versus not treated group. (f) Percentage of healthy POs scored within the ovarian fragments after $24 \mathrm{~h}$ of culture with/out Cs plus LH plus U0126: $10 \mu \mathrm{M} \mathrm{Cs}=34 \pm 3.5 ; 10 \mu \mathrm{M} \mathrm{Cs}+10 \mu \mathrm{M}$ U0126 $=63 \pm 2.9 ; 10 \mu \mathrm{M}$ Cs+200 mIU LH $+10 \mu \mathrm{M}$ U0126 $=65 \pm 4.6$. Statistical differences are versus $\mathrm{Cs}$ group

cells (a human breast adenocarcinoma cell line) expressing LHR (Figure 4d). We found that the addition of $\mathrm{LH}$ resulted effective only when follicles were co-cultured onto the ovarian cells, but not onto MCF-7 monolayers.

LH reduces TAp63 levels in Cs-treated oocytes. Previous studies by us and others have identified TAp63, specifically expressed by oocytes, as a key mediator of POs apoptosis, following IR or Cs treatment. We then investigated whether LH stimulation modulated TAp63 activity and apoptosis in the oocytes exposed to Cs.

Actually, LH was able to reduce TAp63 protein levels as well as caspase 3 activation in POs from P4 ovaries following Cs exposure (Figures $5 \mathrm{a}$ and $\mathrm{b}$ and Supplementary Figures $3 \mathrm{~A}$ and $3 B$ ).

LH and FRSK favor DNA repair in Cs-treated oocytes. Citotoxic effects of Cs are largely mediated by DNA damage. In order to detect DNA damage in the POs, we used antibodies against $\gamma \mathrm{H} 2 \mathrm{AX}$, a marker of DNA double-strand breaks. By IF, we observed that while in the control ovarian fragments $\mathrm{yH} 2 \mathrm{AX}$-positive POs were virtually absent throughout the 24-h culture period, their number markedly increased after $12 \mathrm{~h}$ of $\mathrm{Cs}$ treatment $(36 \% \pm 5.7)$, reaching $66 \% \pm 6.4$ in the few POs survived after $24 \mathrm{~h}$. On the other hand, although the initial number of $\mathrm{yH} 2 \mathrm{AX}$-positive POs over the first $12 \mathrm{~h}$ after $\mathrm{Cs}$ treatment was not affected by $\mathrm{LH},<5 \%$ of the POs remained $\mathrm{YH} 2 \mathrm{AX}$ positive at $24 \mathrm{~h}$ in the presence of the hormone (Figures $5 c$ and $d$ ). These results indicate that $C s$ causes DNA breaks in the POs irrespective of the presence of $\mathrm{LH}$ and suggest that most of the DNA breaks were repaired in the surviving oocytes after $24 \mathrm{~h}$ in the presence of the hormone. As shown in Figure 5e, Cs-treated POs underwent a similar DNA repair kinetics in the presence of FRSK. Differently, in the presence of $\mathrm{KL}$ the most part of the surviving Cs-treated oocytes appeared still $\mathrm{\gamma H} 2 \mathrm{AX}$ positive, after $24 \mathrm{~h}$ of culture (Figure $5 \mathrm{e}$ ), suggesting that cAMP and $\mathrm{KL}$ generating signals prevent $\mathrm{PO}$ apoptosis by different mechanisms.

Staining of $\mathrm{\gamma H} 2 \mathrm{AX}$-positive ovarian somatic cells was significantly prevented by incubation with $\mathrm{LH}$ and $\mathrm{Cs}$ as compared with cells treated with Cs alone, suggesting that in ovarian somatic cells $\mathrm{LH}$ is able to prevent the DNA damage caused by the drug rather than to favor DNA repair machinery (Supplementary Figures $4 a$ and b).

LH preserves ovarian reserve and fertility after Cs treatment. In order to determine whether LH was also effective in protecting the POs pool of the ovarian reserve in vivo, P4-5 mice were divided in four experimental groups and injected with physiological solution (control), LH, Cs or $\mathrm{LH}+\mathrm{Cs}$. We found that 5 days after treatment, the number of primordial follicles, determined by the analysis of histological sections, was drastically reduced in the group treated with $\mathrm{Cs}$ alone but not in that co-treated with $\mathrm{LH}$, indicating a robust protective effect of $\mathrm{LH}$ on the ovarian reserve (Figures 6a and b). 
a

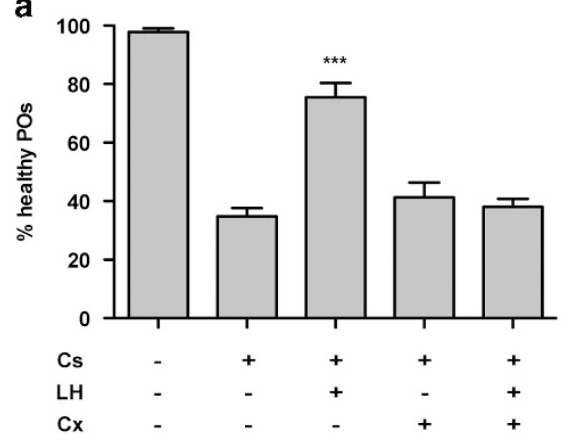

b

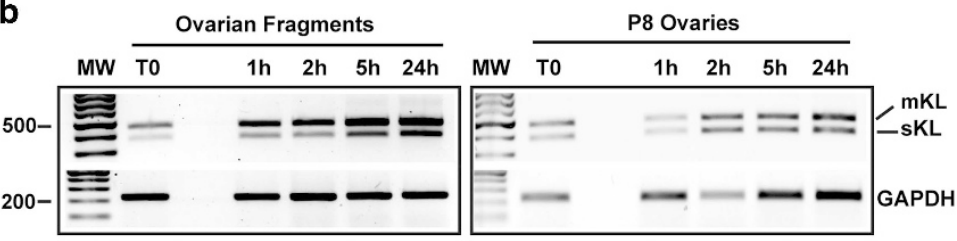

c

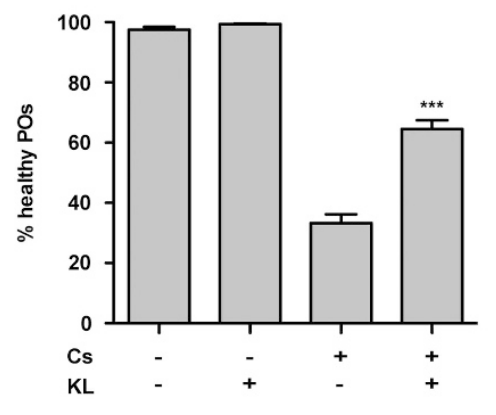

d

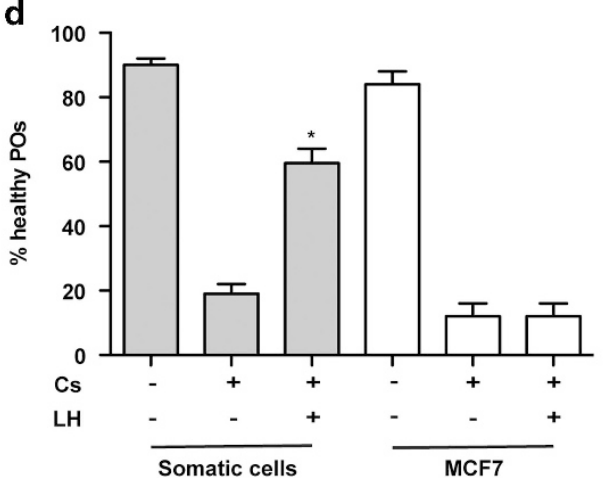

Figure 4 LH ovoprotection against Cs requires functional gap junctions and can be replaced by KL. (a) Percentage of healthy POs scored within the ovarian fragments after $24 \mathrm{~h}$ of culture with/out Cs plus LH or plus LH and Cx (an inhibitor of gap junction): $10 \mu \mathrm{M} \mathrm{Cs}=35 \pm 2.8 ; 10 \mu \mathrm{M} \mathrm{Cs} \pm 200 \mathrm{mlU} \mathrm{LH}=76 \pm 4.9 ; 10 \mu \mathrm{M} \mathrm{Cs}+100 \mu \mathrm{M} \mathrm{Cx}=41 \pm 5.1$; $10 \mu \mathrm{M} \mathrm{Cs}+200 \mathrm{mlU} \mathrm{LH}+100 \mu \mathrm{M} \mathrm{CX}=38 \pm 2.8$. Cx alone did not significantly affect PO survival in comparison with control (data not shown). Statistical differences are versus $\mathrm{Cs}$ groups. (b) A representative RT-PCR (out of at least two performed in different samples) for soluble (s) and membrane (m)-bound KL transcripts in P8 ovarian fragments and ovaries treated for 1-24 h with $200 \mathrm{mIU} \mathrm{LH}$. (c) Percentage of healthy POs scored within the ovarian fragments after $24 \mathrm{~h}$ of culture with/out Cs or plus KL: $10 \mu \mathrm{M} \mathrm{Cs}=33 \pm 2.8$; $10 \mu \mathrm{M} \mathrm{Cs}+100 \mathrm{ng} / \mathrm{ml} \mathrm{KL}=65 \pm 3.0$. Statistical differences are versus Cs groups. (d) Percentage of healthy follicle-enclosed POs scored after 24-h culture with/out Cs plus LH onto cell monolayers obtained from ovarian somatic cells of P8 ovaries (10 $\mu \mathrm{M} \mathrm{Cs}=19 \pm 3.0 ; 10 \mu \mathrm{M} \mathrm{Cs}+200 \mathrm{mlU} \mathrm{LH}=60 \pm 4.5)$, or from MCF-7 cell line (10 $\mu \mathrm{M}$ Cs $=12 \pm 4.0$; $10 \mu \mathrm{M} \mathrm{Cs}+200 \mathrm{mlU} \mathrm{LH}=12 \pm 4.0)$. Statistical differences are versus Cs groups

Next, females of each group were let to grow and analyzed for their reproductive capacity, monitoring their mating capability and the number of pups delivered during seven breeding rounds. We observed that fertility was progressively impaired in females injected with $\mathrm{Cs}$ at the prepubertal age, whereas no significant alterations in the number of pregnancy and delivered pups were found in the $\mathrm{LH}+\mathrm{Cs}$ group in comparison with control (Figures $6 \mathrm{c}$ and $\mathrm{d}$ ). In addition, no evident differences in development and behavior were observed between the newborns from the two groups during the first postnatal week. The gross morphology and the analysis of histological sections of the ovaries at the end of the mating experiments, confirmed the nearly total absence of follicles in the Cs-treated females and normal ongoing folliculogenesis in control as well as in LH+Cs groups (Figures $6 e$ and f).

\section{Discussion}

In this article, we focused on the possibility to use gonadotropins with targeted action on the ovary as 'fertoprotective agents' against a widely used chemotherapic and gonadotoxic drug as Cs. Our in vitro assay was performed on prepubertal ovaries, which contain almost only primordial follicles, representing the ovarian reserve. We demonstrated that $\mathrm{LH}$ at physiological concentrations (around $2.3 \mathrm{ng} / \mathrm{ml}$ ), preserved most of the POs against Cs-induced apoptosis. Furthermore, the protective effect of $\mathrm{LH}$ against $\mathrm{Cs}$ on $\mathrm{PO}$ in vitro was reproducible in vivo, on $\mathrm{P} 4$ mice, that have an immature hypothalamic-pituitary-gonad axis and therefore ovaries not exposed to the $\mathrm{LH}$ concentrations used in our assay. As expected, as oocytes do not express LHR, the protection was indirect and mediated by the ovarian somatic cells. The pregranulosa cells surrounding isolated primordial follicle appeared alone unable or insufficient to protect the oocyte from Cs following $\mathrm{LH}$ incubation. Thus, indicating that $\mathrm{LH}$ ovoprotection requires signaling from different or more numerous pregranulosa cells.

The apparent resistance to Cs of the GOs present in the ovarian tissues in our assay is in line with similar observations. $3,7,8,41$ The reason of insensitivity was not investigated, but it could be due progressive loss of the proapoptotic TAp63 expression from the late primary oocyte stage onward. ${ }^{3,7,8,42}$

$\mathrm{LH}$, upon activation of its receptor, can modulate cAMP/PKA and PI3K/AKT signaling; ${ }^{37}$ accordingly, we found that $\mathrm{LH}$ increased the level of CAMP and the AKT activity in ovarian fragments and $\mathrm{PKA}$ or $\mathrm{PI} 3 \mathrm{~K}$ inhibitors abolished $\mathrm{LH}$ protective effects. Moreover, compounds that mimic or increase intracellular CAMP such as $8 \mathrm{Br}-\mathrm{CAMP}$ and FRSK, respectively, 
a
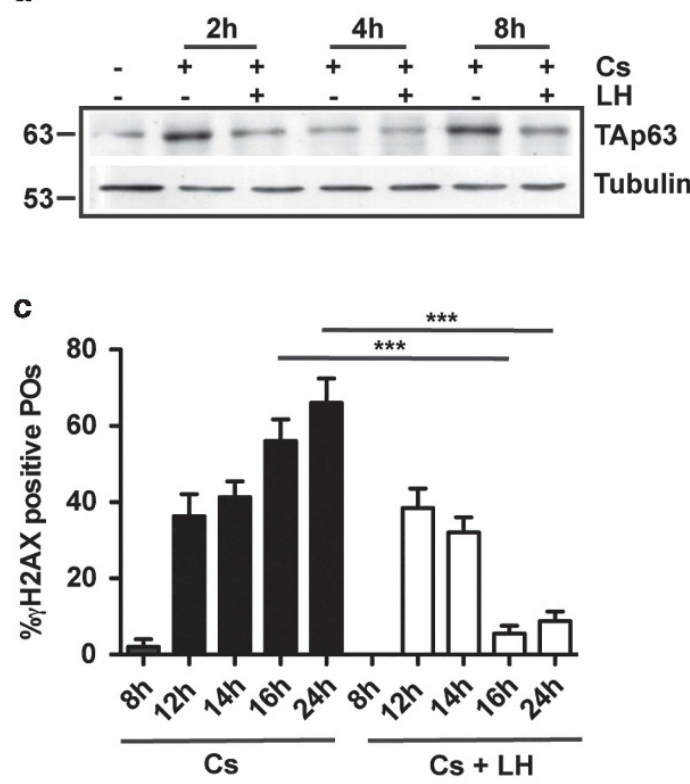

e

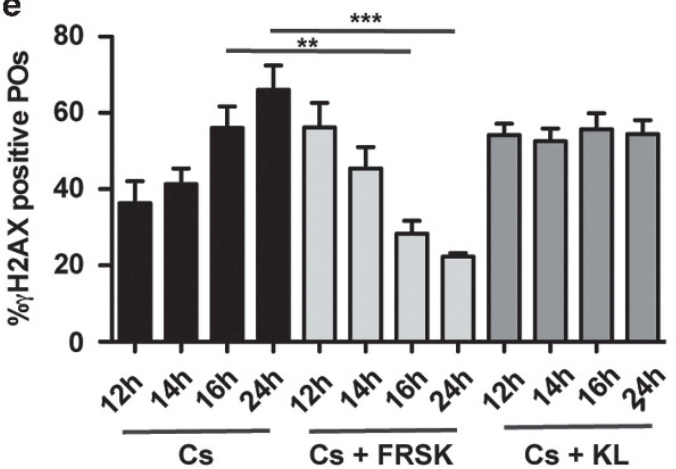

b

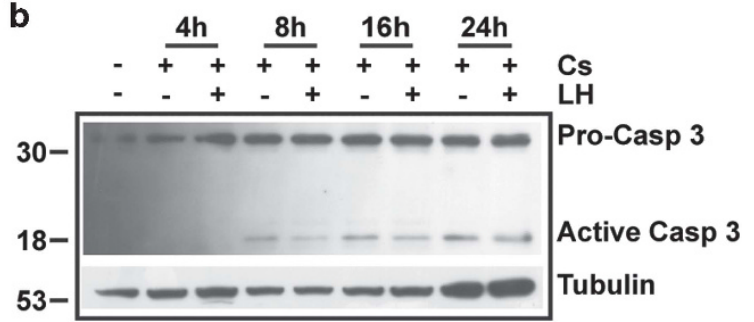

d
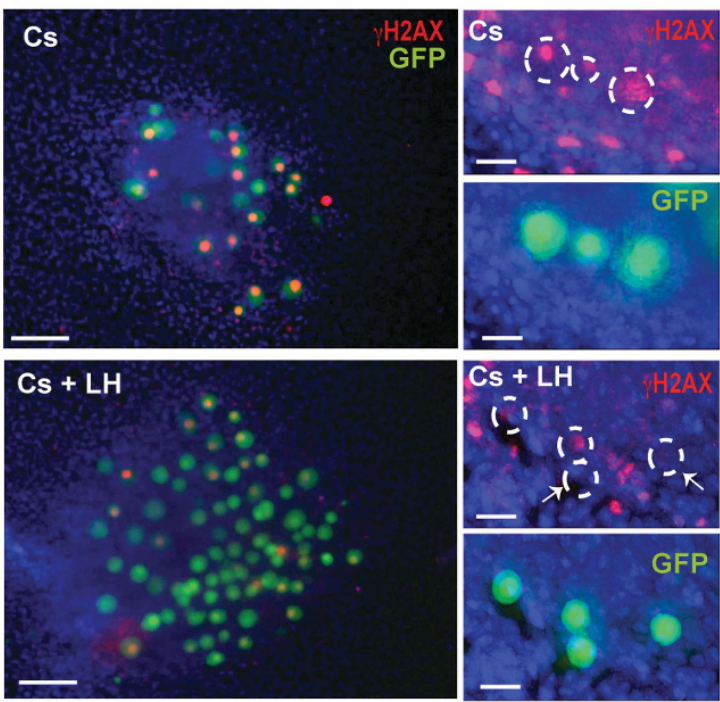

Figure 5 LH reduces TAp63 levels and apoptosis and favors DNA repair in Cs-treated POs. (a) A representative western blot of TAp63 in protein extracts of P8 ovaries incubated for different time with/out Cs plus LH. (b) A representative western blot for pro-caspase 3 and activated caspase 3 in protein extracts of P8 ovaries incubated for different time with/out $10 \mu \mathrm{M}$ Cs plus $200 \mathrm{mlU} \mathrm{LH}$. The analyses were repeated at least two times in different samples. (c) Percentage of $\gamma \mathrm{H} 2 \mathrm{AX}$-positive POs within ovarian fragments cultured for different time with/out $10 \mu \mathrm{M}$ Cs plus $200 \mathrm{mlU}$ LH. Statistical differences are versus Cs groups. (d) Representative IFs of ovarian fragment cultured for $16 \mathrm{~h}$ with/out Cs and LH stained with $\gamma \mathrm{H} 2 \mathrm{AX}$ (red). Scale bar $75 \mu \mathrm{m}$. On the right a magnification of the fragment; dotted rings indicate GFP-positive oocytes; arrows indicates oocytes not stained with $\gamma \mathrm{H} 2 \mathrm{AX}$. Scale bar $25 \mu \mathrm{M}$. (e) Percentage of $\gamma \mathrm{H} 2 \mathrm{AX}$ positive POs within ovarian fragments cultured for different time with/out $10 \mu \mathrm{M} \mathrm{Cs}$ plus $10 \mu \mathrm{M}$ FRSK and $100 \mathrm{ng} / \mathrm{ml} \mathrm{KL}$. Statistical differences are versus Cs groups. The values represent the mean \pm S.E. of at least three independent experiments in which at least three fragments were scored for each experimental condition at each incubation time

were able to partly or completely replace LH in its ovoprotective effect.

Several studies have indicated that the Kit ligand $(\mathrm{KL})$, produced by granulosa cells, and its receptor Kit, expressed by theca cells and oocytes, exert crucial roles during early oogenesis, including anti-apoptotic effect on primordial follicle and oocyte survival, relevant in the present framework. ${ }^{43,44}$ Accordingly to previous papers, ${ }^{40}$ we found that $\mathrm{LH}$ stimulation increased $\mathrm{KL}$ expression and that $\mathrm{KL}$ was able to replace the ovoprotection exerted by $\mathrm{LH}$ against $\mathrm{Cs}$ in the ovarian tissues and fragments.

Whether LH ovoprotection finally results in the activation of cAMP/PKA and PI3K/AKT pathways in the oocytes remains to be investigated. Notwithstanding, it appeared to require the maintenance of functional gap junctions in the ovarian tissues, as it did not occur in the presence of a gap junction blocker. It can be speculated that following LH stimulation, ovarian cells exchange among them and/or pass to the oocytes through gap junctions signals (i.e., cAMP) and metabolites necessary for an effective response against the Cs-induced cytotoxicity. In this regard, others studies have demonstrated that in the adult ovary, LH stimulates the meiotic resumption of the fully growth oocytes both by triggering the closure of gap junction among the LHR-expressing follicular cells and a positive stimulus passing through the gap junctions between the cumulus cells and the oocyte. ${ }^{45,46}$

Considering that $\mathrm{PO}$ express high level of the $\mathrm{KL}$ receptor Kit and the well-known anti-apoptotic effect of the KL/Kit system on such oocytes, ${ }^{35,44}$ it appears likely that besides through gap junctions, the LH-responsive ovarian somatic cells can send anti-Cs cytotoxicity signals to POs via such system. 


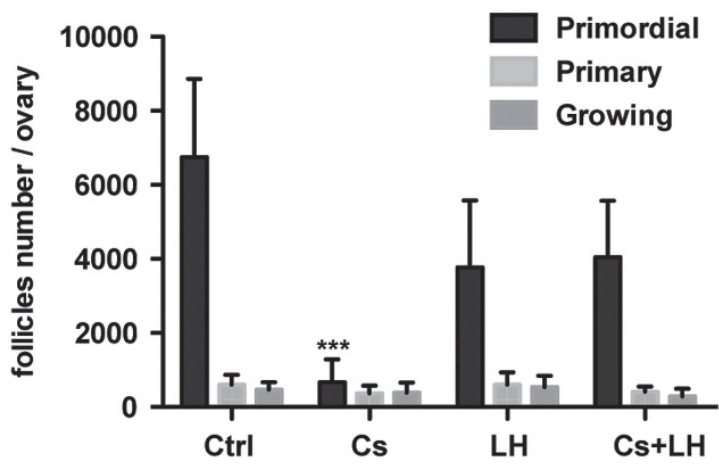

C

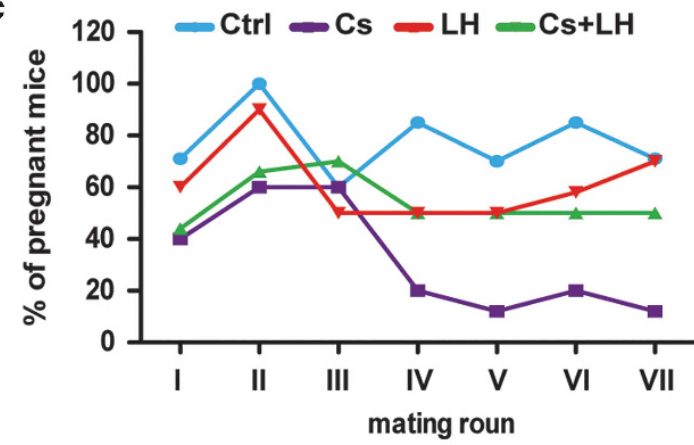

e

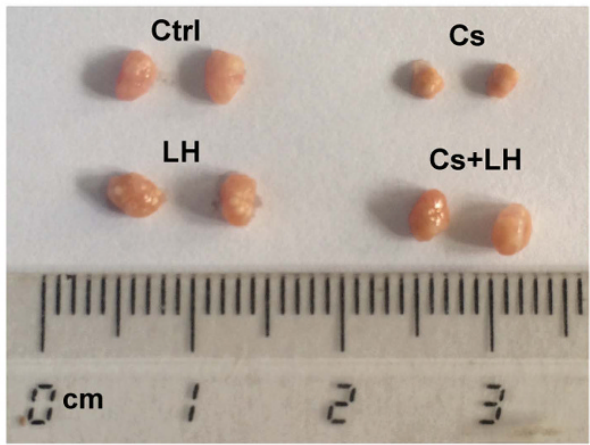

b

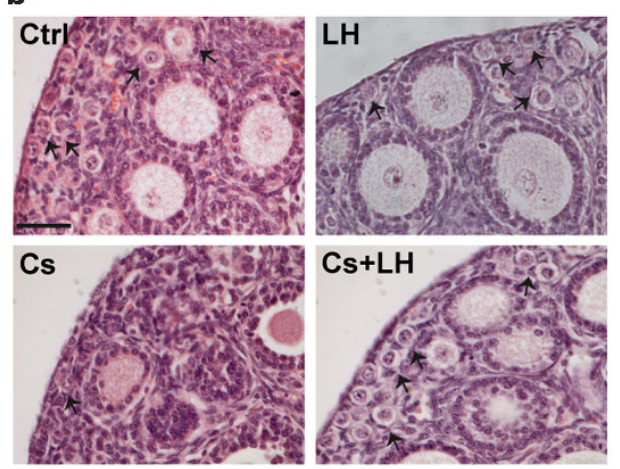

d

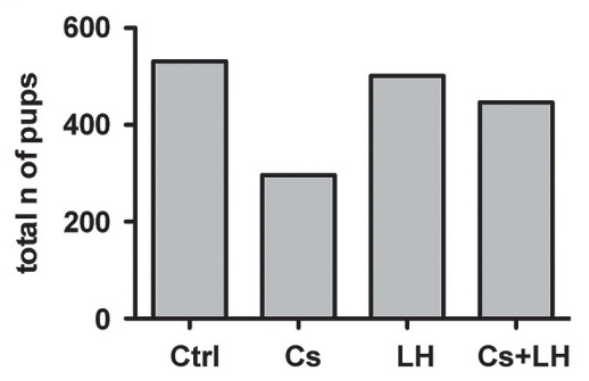

f
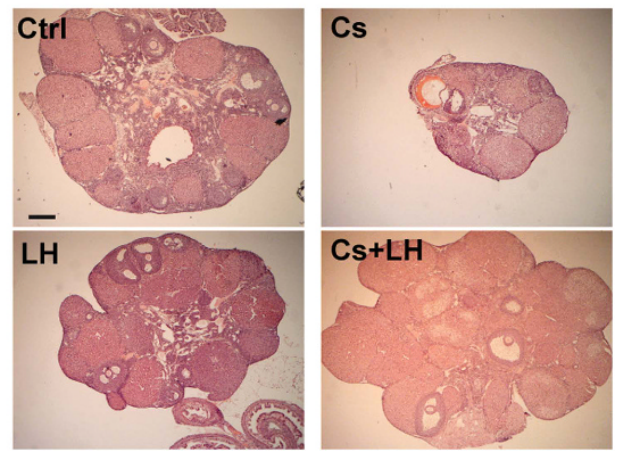

Figure 6 LH preserves ovarian reserve and fertility in Cs-treated prepuberal mice. (a) Quantification of total number of primordial, primary and growing follicles in ovaries dissected from four mice of each experimental groups (Ctrl, Cs, LH and CS+LH); for each group five ovaries were scored. (b) Representative H\&E histological sections of ovaries of the experimental groups. Arrows indicate primordial follicles, almost absent in Cs. Note a not healthy growing follicle in Cs. Scale bar $50 \mu \mathrm{m}$. (c) Percentage of pregnancy rate of the experimental groups throughout VII mating rounds. (d) Total number of pups delivered by the females of each experimental group. (e) Gross morphologies of ovaries dissected from adult mice of the experimental groups at the end of the mating rounds. (f) Representative H\&E histological sections of the ovaries showed in (e). Scale bar $100 \mu \mathrm{m}$

FRSK and $\mathrm{KL}$ are shown here to counteract Cs-induced oocyte death also on isolated follicle-enclosed and denuded POs. These results indicate that PKA and PI3K/AKT activities, this latter known to be downstream the activation of Kit, ${ }^{47,48}$ are crucially involved in the internal molecular mechanisms of the oocytes, saving them from $\mathrm{Cs}$. It remains to define whether cAMP passing through the gap junctions and KL produced by the ovarian cells surrounding the oocytes, are actually the direct and only mediators of the LH ovoprotective effect in our system.

The experiments, aimed to elucidate the oocyte response mechanisms against $\mathrm{Cs}$ underlying $\mathrm{LH}$ ovoprotection, indicated that these impinge on reducing TAp63 levels and favoring the repair of DNA damage occurring as a consequence of $\mathrm{Cs}$ treatment. These latter results are particularly relevant because they suggest that oocytes surviving in the presence of the hormone, not only are protected from apoptosis but do not carry permanent DNA damage. The observation that FRSK determined DNA repair kinetics in oocytes similar to LH suggest that the DNA repair in oocytes can be modulated by PKA dependent signaling.

The observed different kinetics of DNA damage and repair in oocytes following Cs treatment in the presence of FRSK and $\mathrm{KL}$ imply that while stimulation of PKA activity saves oocytes from apoptosis favoring/accelerating DNA repair, PI3K/AKT promotes oocytes survival though distinct mechanisms, involving anti-apoptotic cytoplasmic response. Whereas the cAMP signaling system was reported to have important role in 
modulation of DNA damage repair pathways, its action can be either favoring or inhibiting such pathways depending on the cell type and activity. ${ }^{49-51}$ On the other hand, it is known that the anti-apoptotic PI3K/AKT effect can target both DNA repair and pro-survival cytosolic pathways. ${ }^{52}$ Interestingly, the kinetics of the $\mathrm{yH} 2 \mathrm{AX}$ DNA foci in the ovarian somatic cells showed that in these cells LH prevented the bulk of the DNA breaks generated by $\mathrm{Cs}$ rather than favor their repair.

$\mathrm{GnRH}$ agonist administration is considered among the strategies to preserve ovarian function in adolescent patients treated with certain chemotherapy drugs, although its efficacy and mechanisms of action is still debated. ${ }^{25,26,53,54}$ Several groups reported that $\mathrm{GnRH}$ agonist-treated cancer patients resumed cyclic ovarian function, whereas patients in the chemotherapy alone group experienced amenorrhea. ${ }^{55,56}$ Ataya et al. ${ }^{21}$ showed that $\mathrm{GnRH}$ agonists administrated in parallel with cyclophosphamide significantly decreased the daily rate of follicular decline and the total number of primordial follicles lost during the chemotherapeutic insult. Furthermore, it has been recently shown that $\mathrm{GnRHa}$ co-treatment with $\mathrm{Cs}$, induced, in human ovarian cortical samples, an increase of cAMP levels, ${ }^{54}$ although no protection was seen. Our findings highlight the role of $\mathrm{LH}$-induced cAMP in follicle cells for $\mathrm{PO}$ protection after gonadotoxic treatments and support a possible direct role of $\mathrm{GnRH}$ agonist on the prepuberal ovary, in the preservation of ovarian function in young cancer patients.

In conclusion, we report a novel unexpected effect of LH on mouse primordial follicles of prepubertal ovaries, resulting in robust protection of the oocytes against $\mathrm{Cs}$-induced apoptosis and preserving fertility at adult age. Our results indicate that at this early developmental stage, the ovary is responsive to the hormone and that LH-responsive cells may send signals to the primordial follicle-enclosed oocytes able to modulate their response to DNA-damaging compounds. These findings beside to develop new concepts about the role of $\mathrm{LH}$ in folliculogenesis and the DNA repair mechanisms of POs, may drive the development of a more physiological 'fertoprotective' strategy for young female cancer patients.

\section{Materials and Methods}

Animals. CD-1 and transgenic p-18 GFP/c-Kit mice ${ }^{57}$ were housed and mated under standard laboratory conditions in an environmentally controlled room and treated using humane care in order to inflict the least possible pain. All experiments were approved by the Institutional Animal Care and Use Committee (IACUC) and carried out according to the Italian and European rules (D.L.116/92; C.E. 609/86; European Directive 2010/63/EU).

Compounds and antibodies. The following compounds have been used: Cs, wortmannin, H89, LY294002, U0126, 8-Bromo-cAMP, FRSK, carboxenolone (all from Sigma-Aldrich, Gallarate, Italy), human highly purified recombinant LH and human highly purified recombinant FSH (Merck-Serono, Rome, Italy), recombinant human KL and EGF (Immunological Sciences, Rome, Italy).

The following primary antibodies were used: p63 (4A4-Santa Cruz, Santa Cruz, CA, USA), tubulin (T9026 Sigma-Aldrich), AKT (Biosource, San Diego, CA, USA), phospho-AKT (Immunological Science), $\gamma \mathrm{H} 2 \mathrm{AX}$ (ser 139 Millipore, Vimodrome, MI, Italy), LHR (H-50 Santa Cruz), caspase 3 (9662 Cell Signaling, Danvers, MA, USA), actin (A2066 Sigma-Aldrich).

Ovary culture. Ovarian tissues were cultured as described in Maiani et al. ${ }^{13}$ Briefly, ovaries were collected from P4 transgenic $p-18 \mathrm{GFP} / c-K i t$ mice, in which all oocytes, expressing c-Kit, are GFP positive. Each ovary was sliced into 7-8 pieces and cultured in $\alpha$-MEM (Aurogene, Rome, Italy), supplemented with 10\% FBS (Gibco, Waltham, MA, USA), L-glutammine, penicillin-G and streptomycin, pyruvic acid, $N$-acetyl-L-cysteine and ITS liquid media supplement (100x), hereafter termed as $\mathrm{CM}$, (all from Sigma-Aldrich), for 4 day at $37^{\circ} \mathrm{C}$ in $5 \% \mathrm{CO}_{2}$. At this time, when the ovarian fragments formed a thin layer of tissue containing follicles with visible oocytes under a fluorescence inverted microscope, the number of morphologically healthy GFP-positive oocytes with a diameter $<20 \mu \mathrm{m}$ (POs) was scored (T0 time point) and drugs were added to the culture medium at the indicated concentrations for further $24 \mathrm{~h}$. Oocyte morphology and GFP positivity were analyzed with a Leica CTR 6000 microscope (Watzlar, Germany) at approximately 300X.

Oocyte and primordial follicles culture. Ovaries from P5 CD-1 or p-18 GFP/c-Kit mice were mechanically fragmented and incubated in $0.5 \mathrm{mg} / \mathrm{ml}$ type IV collagenase (Sigma-Aldrich) for $1 \mathrm{~h}$ at $37^{\circ} \mathrm{C}$, followed by $30 \mathrm{~min}$ at $37^{\circ} \mathrm{C}$ in $40 \mathrm{mM}$ EDTA+DNase. After mechanical disaggregation, cells were dispersed and the cell suspension cultured for $6 \mathrm{~h}$ in $\mathrm{CM}$ at $37{ }^{\circ} \mathrm{C}$ in $5 \% \mathrm{CO}_{2}$. Oocytes floating onto the somatic cell monolayer were collected with a mouth-operated pipette, divided into experimental groups according to the diameter $(<$ or $>20 \mu \mathrm{M})$ and cultured in 24-wells in $\mathrm{CM}$ for $24 \mathrm{~h}$ at $37^{\circ} \mathrm{C}$ in $5 \% \mathrm{CO}_{2}$.

Ovaries from P5 CD-1 or p-18 GFP/c-Kit mice were mechanically fragmented and incubated in $1 \mathrm{mg} / \mathrm{ml}$ type I collagenase (Sigma-Aldrich) for $1 \mathrm{~h}$ at $30^{\circ} \mathrm{C}$ in continuous shaking, followed by mechanical disaggregation. Cell suspension was then filtered through a $40 \mu \mathrm{m}$ filter (Corning, New York, NY, USA) to remove undispersed tissue fragments, ${ }^{58}$ divided into experimental groups and cultured (approximately 200 follicles per well) in $\mathrm{CM}$ for $24 \mathrm{~h}$ at $37^{\circ} \mathrm{C}$ in $5 \% \mathrm{CO}_{2}$.

In co-culture experiments, primordial follicles were cultured for $24 \mathrm{~h}$ at $37^{\circ} \mathrm{C}$ in $5 \%$ $\mathrm{CO}_{2}$ onto monolayers of ovarian somatic cells or MCF-7 cell line (from ATCC, Milan, Italy) up to $70 \%$ confluence in 24 -wells culture plates. Ovarian cell monolayers were obtained from ovaries treated as described in the isolated oocyte culture section.

Immunofluorescence. At the indicated culture times, medium was removed and ovarian fragments were fixed in 4\% paraformaldehyde (PFA) for $20 \mathrm{~min}$ at RT, permeabilized with PBS $-0.01 \%$ Triton for $10 \mathrm{~min}$ and blocked in $3 \% \mathrm{BSA}$ 20 min at RT.

For $\gamma \mathrm{H} 2 \mathrm{AX}$ foci staining, fragments were incubated overnight at $4{ }^{\circ} \mathrm{C}$ with mouse $\gamma \mathrm{H} 2 \mathrm{AX}$ antibody in PBS-T (PBS+0.3\% BSA $+0.01 \%$ Triton). Following three $5-$ min PBS washes, primary antibody was detected with goat anti-mouse antibody (Alexa 568, Molecular Probes, Milan, Italy). Fragments where then incubated with Hoechst, mounted in PBS and glycerol and analyzed by Leica CTR 6000 microscope.

For LHR immunelocalization both in ovarian fragments and ovaries, samples were fixed in $4 \%$ PFA and the ovaries sectioned (5 $\mu \mathrm{m}$ sections) following standard histological procedures. Both fragments and ovarian sections were incubated overnight at $4^{\circ} \mathrm{C}$ with LHR antibody (Santa Cruz) in PBS-T. Following three PBS washes of 5 min, primary antibody was detected with goat anti-rabbit antibody (Alexa 568). Fragments and sections where then incubated with Hoechst, mounted in PBS and glycerol and analyzed by Leica CTR 6000 and confocal laser scanning LSM 700 microscope. For negative controls, primary antibodies were omitted from the staining procedure.

Western blotting. Samples were lysed in $50 \mathrm{mM}$ Tris- $\mathrm{HCl} \mathrm{pH} \mathrm{7.4,150 \textrm {mM }}$ $\mathrm{NaCl}, 0.5 \% \mathrm{NP}-40,5 \mathrm{mM}$ EDTA, 0.5\% sodium deoxycholate, $1 \mathrm{mM}$ PMSF, $1 \mathrm{mM}$ sodium o-vanadate, $10 \mu \mathrm{g} / \mathrm{ml}$ leupeptine, $10 \mu \mathrm{g} / \mathrm{ml}$ aprotinin supplemented with protease inhibitors (all from Sigma-Aldrich). Samples were homogenized by ultrasonic homogenization and proteins concentration was determined by Bradford assay.

Aliquots of total protein extracts from samples after different treatments were resolved on SDS-polyacrylamide gel and transferred to a PVDF transfer membrane (GE Healthcare, Milan, Italy). Blots were blocked in $5 \%$ non-fat dry milk in PBS-T (PBS+0.05\% Tween 20 ) for $1 \mathrm{~h}$ at RT and then incubated with primary antibodies $0 . \mathrm{n}$. at $4{ }^{\circ} \mathrm{C}$ in $1 \%$ milk in PBS-T. Membranes were incubated with HRP-conjugated secondary antibody for $1 \mathrm{~h}$ at $\mathrm{RT}$ and signals were detected by ImmunoCruz western blotting luminol reagent (Santa Cruz). Immunoblots were quantitatively evaluated using ImageJ software (NIH, Bethesda, MD, USA). Signal intensities of phosphoproteins were normalized to the corresponding protein signals.

RT-PCR. RNA was extracted from total ovary using RNeasy micro kit (Qiagen, Milan, Italy), according to the manufacturer's instructions. c-DNA was synthesized from $1 \mu \mathrm{g}$ of RNA by QuantiTect reverse transcription Kit. RT-PCR analysis was performed using Sigma-Aldrich primers: 
LHCGR fwd: 5'-GCATCTGTAACACAGGCATCCG-3

LHCGR rev: 5'-CGATGAGCGTCTGAATGGACT-3'

KL fwd: $5^{\prime}$-GAATCTCCGAAGAGGCCAGAAACTAGATCCTTTT-3'

$\mathrm{KL}$ rev: 5'-CGTCCACAATTACACCTCTTGAAATTCTCTCTC-3'

GAPDH fwd: $5^{\prime}$-AACTTTGGCATTGTGGAAGG-3

GAPDH rev: 5'-CCGTGTTCCTACCCCCAATGTG-3'.

Drugs treatment of animals. P5 CD-1 female mice $(n=70 ; 14$ per experimental group) were injected intraperitoneally once with $30 \mu \mathrm{l}$ of physiological solution or equal volume of $\mathrm{Cs}$ ( $10 \mu \mathrm{M}$ per mouse), $\mathrm{LH}$ (200 mlU per mouse) or Cs +LH solutions.

Histology. Five days after treatment, four mice were killed and ovaries collected for standard histological procedures and follicle counts in $5 \mu \mathrm{m}$ sections stained with H\&E. The type and the total number of follicles per ovary were estimated as described in Tilly. ${ }^{59}$ Briefly, follicles were counted in every fifth section throughout the entire ovary and the mean total number of follicle per section multiplied by the total number of sections of the ovary. All primordial and primary follicles were counted, whether or not an oocyte nucleus was visible. For growing follicle, only follicles with a visible oocyte nucleus were counted to prevent double counting.

CAMP ELISA. CAMP concentration was evaluated using the direct CAMP ELISA kit (ENZO, Rome, Italy) according to the manufacturer's instructions. Briefly, ovarian tissues obtained from two ovaries of P4 were cultured for 4 days; after incubation for the indicated times (see Supplementary Figure S2), with or without $200 \mathrm{mIU} \mathrm{LH}$ tissues were lysed with $100 \mu \mathrm{l}$ of $0.1 \mathrm{M} \mathrm{HCl}$. After centrifugation at $600 \mathrm{~g}$ for $5 \mathrm{~min}$, the supernatant was treated with the kit reagents and analyzed with a Infinite F50 Tecan (Männedorf, Switzerland).

Mating protocol. Five weeks after treatment, female mice were randomly mated with males of proven fertility (one male to two females). Each experimental group (Control, LH, Cs, Cs+LH) consisted of a total of 10 females. Mating was established by the formation of the fertilization plug (within a week of continuous). ${ }^{21}$ All females were then separated from males and those plugged allowed to progress pregnancy until delivery (about 3 weeks). The mothers remained with their pups 1 week before separation. After an additional week (without breast-feeding), all females (previously plugged and unplugged) were mated again. Such mating round was repeated seven times for a total period of about 9 months. The number of pregnancies and pups was counted after each round. At the end of the experiments, ovaries were collected and analyzed with standard histological procedures in paraffin tissue sections.

Statistical analysis. Data were collected from at least three different experiments and analyzed with Graph-pad Prism 6.0 software (La Jolla, CA, USA). $P$-value was determined by one-way Anova followed by Bonferroni analyses comparing all groups of data. Statistical significance was based on $P$ value: ${ }^{*}<0.05,{ }^{* *}<0.001,{ }^{* * *}<0.0001{ }^{59}$

\section{Conflict of Interest}

The authors declare no conflict of interest.

Acknowledgements. This work was financially supported by Merck-Serono SPA, Italy, an affiliate of Merck KGaA, Darmstadt, Germany. We thank Mr. Gabriele Rossi for the preparation of the histological sections.

1. De Felici M, Barrios F. Seeking the origin of female germline stem cells in the mammalian ovary. Reproduction 2013; 146: 125-30.

2. Oktem O, Oktay K. Quantitative assessment of the impact of chemotherapy on ovarian follicle reserve and stromal function. Cancer 2007; 110: 2222-2229.

3. Gonfloni S, Di Tella L, Caldarola S, Cannata SM, Klinger FG, Di Bartolomeo C et al. Inhibition of the c-Abl-TAp63 pathway protects mouse oocytes from chemotherapy-induced death. Nat Med 2009; 15: 1179-1185.

4. Salama M, Woodruff TK. New advances in ovarian autotransplantation to restore fertility in cancer patients. Cancer Metastasis Rev 2015; 34: 807-822.

5. Woodruff TK. Preserving fertility during cancer treatment. Nat Med 2009; 15: 1124-1125.

6. Kurita T, Cunha GR, Robboy SJ, Mills AA, Medina RT. Differential expression of p63 isoforms in female reproductive organs. Mech Dev 2005; 122: 1043-1055.
7. Suh EK, Yang A, Kettenbach A, Bamberger C, Michaelis AH, Zhu Z et al. p63 protects the female germ line during meiotic arrest. Nature 2006; 444: 624-628.

8. Livera G, Petre-Lazar B, Guerquin MJ, Trautmann E, Coffigny H, Habert R et al. p63 null mutation protects mouse oocytes from radio-induced apoptosis. Reproduction 2008; 135 3-12.

9. Bolcun-Filas E, Rinaldi VD, White ME, Schimenti JC. Reversal of female infertility by Chk2 ablation reveals the oocyte DNA damage checkpoint pathway. Science 2014; 343 : 533-536.

10. Vandormael-Pournin S, Guigon CJ, Ishaq $M$, Coudouel N, Avé $P$, Huerre $M$ et al. Oocyte-specific inactivation of Omcg1 leads to DNA damage and c-Abl/TAp63-dependent oocyte death associated with dramatic remodeling of ovarian somatic cells. Cell Death Differ 2015; 22: 108-117.

11. Maiani E, Di Bartolomeo C, Klinger FG, Cannata SM, Bernardini S, Chateauvieux S et al. Reply to: cisplatin-induced primordial follicle oocyte killing and loss of fertility are not prevented by imatinib. Nat Med 2012; 18: 1172-1174.

12. Kerr JB, Hutt KJ, Michalak EM, Cook M, Vandenberg CJ, Liew SH et al. DNA damageinduced primordial follicle oocyte apoptosis and loss of fertility require TAp63-mediated induction of Puma and Noxa. Mol Cell 2012; 48: 343-352.

13. Kim SY, Cordeiro MH, Serna VA, Ebbert K, Butler LM, Sinha S et al. Rescue of platinumdamaged oocytes from programmed cell death through inactivation of the p53 family signalling network. Cell Death Differ 2013; 20: 987-997.

14. Hancke K, Strauch O, Kissel C, Göbel H, Schäfer W, Denschlag D. Sphingosine $1-$ phosphate protects ovaries from chemotherapy-induced damage in vivo. Fertil Steril 2007; 87: 172-177.

15. Zelinski MB, Murphy MK, Lawson MS, Jurisicova A, Pau KY, Toscano NP et al. In vivo delivery of FTY720 prevents radiation-induced ovarian failure and infertility in adult female nonhuman primates. Fertil Steril 2011; 95: 1440-1445.

16. Tan SJ, Lee LJ, Tzeng CR, Wang CW, Hsu MI, Chen CH. Targeted anti-apoptosis activity for ovarian protection against chemotherapy-induced ovarian gonadotoxicity. Reprod Biomed Online 2014; 29: 00423-00424.

17. Roti EC, Salih SM. Dexrazoxane ameliorates doxorubicin-induced injury in mouse ovarian cells. Biol Reprod 2014; 29: 612-620.

18. Kalich-Philosoph L, Roness H, Carmely A, Fishel-Bartal M, Ligumsky H, Paglin S et al. Cyclophosphamide triggers follicle activation and "burnout"; AS101 prevents follicle loss and preserves fertility. Sci Transl Med 2013; 185: 5.

19. Taskin MI, Yay A, Adali E, Balcioglu E, Inceboz U. Protective effects of sildenafil citrate administration on cisplatin-induced ovarian damage in rats. Gynecol Endocrinol 2015; 31 272-277.

20. Ting AY, Petroff BK. Petroff, challenges and potential for ovarian preservation with SERMs. Biol Reprod 2015; 92: 133

21. Ataya K, Rao LV, Lawrence E, Kimmel R. Luteinizing hormone-releasing hormone agonist inhibits cyclophosphamide-induced ovarian follicular depletion in rhesus monkeys. Biol Reprod 1995; 52: 365-372.

22. Blumenfeld Z, Avivi I, Linn S, Epelbaum R, Ben-Shahar M, Haim N et al. Prevention of irreversible chemotherapy-induced ovarian damage in young women with lymphoma by a gonadotrophin-releasing hormone agonist in parallel to chemotherapy. Hum Reprod 1996; 11: $1620-1626$.

23. Blumenfeld Z. Gynaecologic concerns for young women exposed to gonadotoxic chemotherapy. Curr Opin Obstet Gynecol 2003; 15: 359-370.

24. Blumenfeld $Z$. How to preserve fertility in young women exposed to chemotherapy? The role of $\mathrm{GnRH}$ agonist cotreatment in addition to cryopreservation of embrya, oocytes, or ovaries. Oncologist 2007; 12: 1044-1054.

25. Horicks F, Van Den Steen G, Houben S, Englert Y, Demeestere I. Folliculogenesis is not fully inhibited during $\mathrm{GnRH}$ analogues treatment in mice challenging their efficiency to preserve the ovarian reserve during chemotherapy in this model. PLOS One 2015; 10: e0137164.

26. Kim SY, Kim SK, Lee JR, Woodruff TK. Toward precision medicine for preserving fertility in cancer patients: existing and emerging fertility preservation options for women. J Gynecol Oncol 2016; $27: 2$.

27. Panigone S, Hsieh M, Fu M, Persani L, Conti M. Luteinizing hormone signaling in preovulatory follicles involves early activation of the epidermal growth factor receptor pathway. Mol Endocrinol 2008; 22: 924-936.

28. Zhang M, Su YQ, Sugiura K, Wigglesworth K, Xia G, Eppig JJ et al. Estradiol promotes and maintains cumulus cell expression of natriuretic peptide receptor 2 (NPR2) and meiotic arrest in mouse oocytes in vitro. Endocrinology 2011; 152: 4377-4385.

29. Kawamura K. Pre-ovulatory LH/hCG surge decreases C-type natriuretic peptide secretion by ovarian granulosa cells to promote meiotic resumption of pre-ovulatory oocytes. Hum Reprod 2011; 26: 3094-3101.

30. Chun SY, Billig H, Tilly JL, Furuta I, Tsafriri A, Hsueh AJ et al. Gonadotropin suppression of apoptosis in cultured preovulatory follicles: mediatory role of endogenous insulin-like growth factor I. Endocrinology 1994; 135: 1845-1853.

31. Oktay K, Briggs D, Gosden RG. Ontogeny of follicle-stimulating hormone receptor gene expression in isolated human ovarian follicles. J Clin Endocrinol Metab 1997; 82: 3748-3751.

32. McGee E. Preantral ovarian follicles in serum-free culture: suppression of apoptosis after activation of the cyclic guanosine $3^{\prime}, 5^{\prime}$-monophosphate pathway and stimulation of growth and differentiation by follicle-stimulating hormone. Endocrinology 1997; 138: 2417-2424 
33. Wu J, Nayudu PL, Kiesel PS, Michelmann HW. Luteinizing hormone has a stage-limited effect on preantral follicle development in vitro. Biol Reprod 2000; 63: 320-327.

34. Sokka TA, Hämäläinen TM, Kaipia A, Warren AD, Huhtaniemi IT. Development of luteinizing hormone action in the perinatal rat ovary. Biol Reprod 2000; 63: 320-327.

35. O'Shaughnessy PJ, McLelland D, McBride MW. Regulation of luteinizing hormone-receptor and follicle-stimulating hormone-receptor messenger ribonucleic acid levels during development in the neonatal mouse ovary. Biol Reprod 1997; 57: 602-608.

36. Eppig JJ. The participation of cyclic adenosine monophosphate (CAMP) in the regulation of meiotic maturation of oocytes in the laboratory mouse. J Reprod Fertil Suppl 1989; 38: 3-8.

37. Casarini L, Lispi M, Longobardi S, Milosa F, La Marca A, Tagliasacchi D et al. LH and hCG action on the same receptor results in quantitatively and qualitatively different intracellular signalling. PLoS One 2012; 7: e46682.

38. Wright CS, Becker DL, Lin JS, Warner AE, Hardy K. Stage-specific and differentia expression of gap junctions in the mouse ovary: connexin-specific roles in follicular regulation. Reproduction 2001; 121: 77-88.

39. Webb RJ, Marshall F, Swann K, Carroll J. Follicle-stimulating hormone induces a gap junction-dependent dynamic change in [CAMP] and protein kinase a in mammalian oocytes. Dev Biol 2002; 246: 441-454.

40. Ye Y, Kawamura K, Sasaki M, Kawamura N, Groenen P, Gelpke MD et al. Kit ligand promotes first polar body extrusion of mouse preovulatory oocytes. Reprod Biol Endocrinol 2009; 7: 26.

41. Petrillo SK, Desmeules P, Truong TQ, Devine PJ. Detection of DNA damage in oocytes of small ovarian follicles following phosphoramide mustard exposures of cultured rodent ovaries in vitro. Toxicol Appl Pharmacol 2011; 253: 94-102.

42. Amelio I, Grespi F, Annicchiarico-Petruzzelli M, Melino G. p63 the guardian of human reproduction. Cell Cycle 2012; 11: 4545-4551.

43. Reynaud K, Cortvrindt R, Smitz J, Driancourt MA. Effects of Kit Ligand and anti-Kit antibody on growth of cultured mouse preantral follicles. Mol Reprod Dev 2000; 56: 483-494.

44. Hutt KJ, E. McLaughlin A, Holland MK. Kit ligand and c-Kit have diverse roles during mammalian oogenesis and folliculogenesis. Mol Hum Reprod 2006; 12: 61-69.

45. Sela-Abramovich S, Edry I, Galiani D, Nevo N, Dekel N. Disruption of gap junctional communication within the ovarian follicle induces oocyte maturation. Endocrinology 2006; 147: 2280-2286.

46. Downs SM, Chen J. EGF-like peptides mediate FSH-induced maturation of cumulus cell-enclosed mouse oocytes. Mol Reprod Dev 2008; 75: 105-114.

47. Liu K, Rajareddy S, Liu L, Jagarlamudi K, Boman K, Selstam G et al. Control of mammalian oocyte growth and early follicular development by the oocyte PI3 kinase pathway: new roles for an old timer. Dev Biol 2006; 299: 1-11.

48. Miyoshi T, Otsuka F, Nakamura E, Inagaki K, Ogura-Ochi K, Tsukamoto N et al. Mol regulatory role of kit ligand-c-kit interaction and oocyte factors in steroidogenesis by rat granulosa cells. Mol Cell Endocrinol 2012; 358: 18-26.

49. Ghorbani A, Jeddi-Tehrani M, Saidpour A, Safa M, Bayat AA, Zand $\mathrm{H}$ et al. PI3K/AKT and Mdm2 activation are associated with inhibitory effect of CAMP increasing agents on DNA damage-induced cell death in human pre-B NALM- 6 cells. Arch Biochem Biophys 2015; 566: 58-66.
50. Cvijic ME, Yang WL, Chin KV. Cisplatin resistance in cyclic AMP-dependent protein kinase mutants. Anticancer Res 1998; 18(5 A): 3187-3192.

51. Jarrett SG, Wolf Horrell EM, Christian PA, Vanover JC, Boulanger MC, Zou Y et al. PKAmediated phosphorylation of ATR promotes recruitment of XPA to UV-induced DNA damage. Mol Cell 2014; 54: 999-1011.

52. Liu Q, Turner KM, Alfred Yung WK, Chen K, Zhang W. Role of AKT signaling in DNA repair and clinical response to cancer therapy. Neuro Oncol 2014; 16: 1313-1323.

53. Bildik G, Akin N, Senbabaoglu F, Sahin GN, Karahuseyinoglu S, Ince U et al. GnRH agonist leuprolide acetate does not confer any protection against ovarian damage induced by chemotherapy and radiation in vitro. Hum Reprod 2015; 30: 2912-2925.

54. Lambertini M, Ceppi M, Poggio F, Peccatori FA, Azim JrHA, Ugolini D et al. Ovarian suppression using luteinizing hormone-releasing hormone agonists during chemotherapy to preserve ovarian function and fertility of breast cancer patients: a meta-analysis of randomized studies. Ann Oncol 2015; 26: 2408-2419.

55. Lambertini M, Boni L, Michelotti A, Gamucci T, Gori S, Giordano M et al. Long-term outcome results of the phase III PROMISE-GIM6 study evaluating the role of LHRH analog (LHRHa) during chemotherapy as a strategy to reduce ovarian failure in early breast cancer patients. J Clin Oncol 2014; 32: 26.

56. Moore HCF, Unger JM, Phillips KA, Boyle F, Hitre E, Porter D et al. Goreselin for ovarian protection during breast cancer adjuvant chemotherapy. N Engl J Med 2015; 372: 923-932.

57. Cairns LA, Moroni E, Levantini E, Giorgetti A, Klinger FG, Ronzoni S et al. Kit regulatory elements required for expression in developing hematopoietic and germ cell lineages. Blood 102: 2003; 3954-3962.

58. Hornick JE, Duncan FE, Shea LD, Woodruff TK. Woodruff, Isolated primate primordial follicles require a rigid physical environment to survive and grow in vitro. Hum Reprod 2012; 27: $1801-1810$.

59. Tilly JL. Ovarian follicle counts-not as simple as 1, 2, 3. Reprod Biol Endocrinol 2003; 1: $1-11$.

(i) $(9)$ This work is licensed under a Creative Commons Attribution-NonCommercial-NoDerivs 4.0 International License. The images or other third party material in this article are included in the article's Creative Commons license, unless indicated otherwise in the credit line; if the material is not included under the Creative Commons license, users will need to obtain permission from the license holder to reproduce the material. To view a copy of this license, visit http://creativecommons.org/licenses/by-nc-nd/4.0/

(C) The Author(s) 2017

Supplementary Information accompanies this paper on Cell Death and Differentiation website (http://www.nature.com/cdd) 